UDC 544:544,344

\title{
ACTIVATION INFLUENCE ON CATALYTIC ACTIVITY OF CATALYSTS, MODIFIED BY METALS CATIONS OF MORDENITE SYNTHETIC ZEOLITE IN TOLUENE DISPROPORTIONATION REACTION
}

\author{
A.M.Aliev, V.Sh.Aghayev, A.A.Sarijanov, R.Y.Mirzaeva, S.R.Mammedova \\ M.Nagiev Institute of Catalysis and Inorganic Chemistry, NAS of Azerbaijan \\ renaagayeva1952@gmail.com
}

Received 13.09.2018

\begin{abstract}
Catalytic activities of synthetic zeolite $\left(\mathrm{SiO}_{2} / \mathrm{Al}_{2} \mathrm{O}_{3}=18\right)$ - mordenite, modified by metal cations $\left(\mathrm{Pd}^{2+}\right.$, $\left.\mathrm{Ni}^{2+}, \mathrm{Co}^{2+}, \mathrm{Nd}^{3+}, \mathrm{Mo}^{3+}, \mathrm{Zr}^{4+}, \mathrm{Nb}^{5+}\right)$ activated under different air stream conditions in the temperature range of $300-420^{\circ} \mathrm{C}$ in disproportionation reaction of toluene to benzene and xylenes were studied. It was found that mordenite zeolite catalysts comprising $\mathrm{Pd}^{2+}, \mathrm{Ni}^{2+}$ and $\mathrm{Nd}^{3+}$ cations are more active than the catalysts containing $\mathrm{Co}^{2+}, \mathrm{Mo}^{3+}, \mathrm{Zr}^{4+}, \mathrm{Nb}^{5+}$. It has been established that in conditions under study the samples activated in dry-wet air medew (by joint of toulene and xylene) display the most activity and selectivity.
\end{abstract}

Keywords: disproportionation, toluene, zeolite, mordenite, benzene, xylenes, cation, calcination, modification.

Zeolite mordenite catalyst exhibits more activity and selectivity than faujasite type zeolites in disproportionation reaction of toluene $[1,2]$. For toluene disproportionation reactionit is possible to receive highly active and highly selective catalysts at molar ratio in zeolite mordenite catalyst $\mathrm{SiO}_{2}: \mathrm{Al}_{2} \mathrm{O}_{3}$ within frame of cations into it [3-5].

One of the important prospective methods of regulating activity and selectivity of zeolite catalysts is their calcination under various conditions. But, influence of calcination on the activity of a metal-containing mordenite zeolite catalyst in this reaction has not been studied sufficiently [3].

The main goal of the work is to study the effect of calcination of zeolite mordenite catalysts modified with different metal cations on their activity in toluene disproportionation reaction.

\section{Experimental part}

Modification of zeolite H-mordenite $\left(\mathrm{SiO}_{2}: \mathrm{Al}_{2} \mathrm{O}_{3}=\alpha=18\right)$ with cations of different elements $\left(\mathrm{Pd}^{2+}, \mathrm{Ni}^{2+}, \mathrm{Co}^{2+}, \mathrm{Mo}^{3+}, \mathrm{Nd}^{3+}, \mathrm{Zr}^{4+}\right.$, $\mathrm{Nb}^{5+}$ ) was performed in their sold of chloride and nitrate solution using ion-exchange technique. Preparation of zeolite H-mordenite $(\alpha=18)$ is given in the work [4]. Modification with $\mathrm{Pd}^{+2}$ ions was performed in the solution of $\left[\mathrm{Pd}\left(\mathrm{NH}_{3}\right)_{4}\right] \mathrm{Cl}_{2}$ complex salt. Mo H-mordenite catalyst was prepared with using paraammonium molybdate salt solution by absorption method. The content of metal cations in zeolite is about $1.0 \%$ of a zeolite mass.

After drying synthesized catalysts (100$120^{\circ} \mathrm{C}, 8-10 \mathrm{~h}$ ) they are thermally treated at $350^{\circ} \mathrm{C}(5 \mathrm{~h})$ and $500^{\circ} \mathrm{C}(3 \mathrm{~h})$. Prepared catalyst samples are pressed, then granules with sizes of $0.25-0.7 \mathrm{~mm}$ are separated into fractions. The process is carried out in U-shaped flow type reactor, in the temperature range of $300-420^{\circ} \mathrm{C}$, in flow rate of $3.1 \mathrm{~h}^{-1}, \mathrm{H}_{2}: \mathrm{CH}$ (toluene)-3:1 molar ratio, under atmospheric pressure. Volume of catalyst samples in the reactor is $3 \mathrm{~cm}^{3}$, sizes of granules are $0.25-0.63 \mathrm{~mm}$. The reactor is placed into a thermostat equipped with an electric ventilator and after treating the catalyst at $400^{\circ} \mathrm{C}$ for $10 \mathrm{l} / \mathrm{h}$ in dry (d) (dried before in silicagel then $\mathrm{NaX}$ zeolite for $3 \mathrm{~h}$ ), wet (w) (in $50 \%$ of water steam with air for $3 \mathrm{~h}$ ), wet-dry (wd) $(50 \%$ of water steam air mixture for $2 \mathrm{~h}$, on dry air for $1 \mathrm{~h}$ ) and dry-wet (dw) (on dry air for $1 \mathrm{~h}$, wet air for $2 \mathrm{~h}$ ) air stream conditions argon gas is supplied into the system for 5-10 $\min (1.0 \mathrm{l} / \mathrm{h})$ and at the same temperature it is reduced with hydrogen $(8.0 \mathrm{l} / \mathrm{h})$ for 3 hours and the temperature is regulated according to the 
temperature of the experiment, and using NE1600 microdosator toluene is passed with a volume rate to a mixer regulated with thermoregulator XMDT-6000 placed in a thermostatic chamber heated with electric spirals.

Hydrogen is supplied into a mixer from a separate line. Stable temperature is regulated using microelectronic thermoregulator in a thermostat. After toluene and hydrogen are supplied to a mixer toluene passes to a gas phase and toluene-hydrogen mixture enters to the reaction zone through the entrance of the reactor.

Analysis methods of primary reagents and products are given in the work [4]. After the experiment is finished argon gas is supplied with $2-31 / \mathrm{h}$ rate for $10-15 \mathrm{~min}$ and calcinated in air flow at $500^{\circ} \mathrm{C}$ for an hour to extract the reaction products from the reactor.

\section{Results and discussion}

First the effect of thermal treatment of mordenite zeolite catalysts modified with different metal cations $\left(\mathrm{Pd}^{2+}, \mathrm{Ni}^{2+}, \mathrm{Co}^{2+}, \mathrm{Nd}^{3+}\right)$ in dry, wet, dry-wet air stream condition on their catalytic activity in disproportionation of toluene at $350^{\circ} \mathrm{C}$ in $\mathrm{V}=3.1 \mathrm{~h}^{-1}, \quad \mathrm{H}_{2}: \mathrm{CH}=3: 1$ was studied (Table 1.)

As Table 1 shows, mordenite zeolite catalysts modified with different metal cations exhibit various activity in disproportionation of toluene depending on calcination method. It was determined that catalyst samples treated in dry-wet air stream condition exhibit higher activity and selectivity than catalyst samples treated in dry, wet, wet-dry air stream conditions. As a result of the reaction trimetylbenzenes (TMB) and non-aromatic (Non-ar) hydrocarbons are formed together with the target products - benzene and xylenes. Thus, conversion of toluene in the samples treated in dry-wet air stream condition is $41.2-44.2 \%$, joint yield of benzenes and xylenes is in the range of 37.2$42.5 \%$ (selectivity of the process - 90.3$96.2 \%$ ), conversion of toluene in samples treated in dry air stream condition is $30.4-35.2 \%$, joint yield of benzenes and xylenes is 11.3$18.8 \%$ (selectivity of the process $-37.2-56 \%$ ).

It should be noted that the yield and selectivity of benzene and xylenes in the samples calcinated in wet-dry air stream condition are higher than in the samples treated in dry and wet air stream conditions. If the selectivity is in the range of $85.5-89-2 \%$ and the joint yield of benzenes and xylenes is in the range of $33.9-37.3 \%$ in the samples treated in wet-dry air stream condition, these indicators are $62.1-81.3 \%$ and $23.1-30.5 \%$ in the samples treated in wet air stream condition, correspondingly.

Table 1. Catalytic activitie of the catalysts calcinated in dry, wet, wet-dry and dry-wet air stream condition at $400^{\circ} \mathrm{C}$ in disproportionation of toluene, $T=350^{\circ} \mathrm{C}, V=3.1 \mathrm{~h}^{-1}, \mathrm{H}_{2} / \mathrm{CH}=3: 1$

\begin{tabular}{|c|c|c|c|c|c|c|c|c|c|c|c|}
\hline \multirow{2}{*}{$\begin{array}{l}\text { Cata- } \\
\text { lysts }\end{array}$} & \multicolumn{4}{|c|}{ Yield of reaction products, $\%$} & \multirow{2}{*}{$\begin{array}{l}\text { Conver- } \\
\text { sion, \% }\end{array}$} & \multicolumn{4}{|c|}{ Selectivity \% } & \multirow{2}{*}{$\begin{array}{c}\text { Yield of } \\
\sum \mathrm{Xy}+\mathrm{b}, \%\end{array}$} & \multirow{2}{*}{$\begin{array}{c}\text { Selectivity for } \\
\sum \mathrm{Xy}+\mathrm{b}, \%\end{array}$} \\
\hline & benzene & xylenes & TMB & $\begin{array}{c}\text { non-ar } \\
\text { hc }\end{array}$ & & benzene & xylenes & TMB & $\begin{array}{c}\text { non-ar } \\
\text { hc }\end{array}$ & & \\
\hline $\mathrm{K}_{1} \mathrm{~d}$ & 10.2 & 8.6 & 11.3 & 3.5 & 33.6 & 30.4 & 25.6 & 33.6 & 10.4 & 18.8 & 56.0 \\
\hline $\mathrm{K}_{2} \mathrm{~d}$ & 8.1 & 6.8 & 15.2 & 4.1 & 34.2 & 23.7 & 19.9 & 44.4 & 12.0 & 14.9 & 43.6 \\
\hline $\mathrm{K}_{3} \mathrm{~d}$ & 6.2 & 5.1 & 14.5 & 4.6 & 30.4 & 20.4 & 16.8 & 47.7 & 15.1 & 11.3 & 37.2 \\
\hline $\mathrm{K}_{4} \mathrm{~d}$ & 8.3 & 8.1 & 14.6 & 4.2 & 35.2 & 23.6 & 23.0 & 41.5 & 11.9 & 16.4 & 46.6 \\
\hline $\mathrm{K}_{1} \mathrm{~W}$ & 15.7 & 14.8 & 5.1 & 1.9 & 37.5 & 41.9 & 39.5 & 13.6 & 5.1 & 30.5 & 81.3 \\
\hline $\mathrm{K}_{2} \mathrm{~W}$ & 14.1 & 12.6 & 8.2 & 3.5 & 38.4 & 36.7 & 32.8 & 21.4 & 9.1 & 26.7 & 69.5 \\
\hline $\mathrm{K}_{3} \mathrm{~W}$ & 12.9 & 10.2 & 10.3 & 3.8 & 37.2 & 34.7 & 27.4 & 27.7 & 10.2 & 23.1 & 62.1 \\
\hline $\mathrm{K}_{4} \mathrm{~W}$ & 14.7 & 11.6 & 8.3 & 3.5 & 38.1 & 38.6 & 30.4 & 21.8 & 9.2 & 26.3 & 69.0 \\
\hline $\mathrm{K}_{1}$ wd & 19.5 & 17.8 & 3.3 & 1.2 & 41.8 & 46.7 & 42.6 & 7.9 & 2.9 & 37.3 & 89.2 \\
\hline $\mathrm{K}_{2} \mathrm{wd}$ & 18.3 & 16.4 & 4.0 & 1.9 & 40.6 & 45.1 & 40.4 & 9.9 & 4.7 & 34.7 & 85.5 \\
\hline $\mathrm{K}_{3} \mathrm{wd}$ & 18.1 & 15.8 & 4.1 & 1.1 & 39.1 & 46.3 & 40.4 & 10.5 & 2.8 & 33.9 & 86.7 \\
\hline $\mathrm{K}_{4}$ wd & 19.1 & 16.1 & 3.5 & 0.9 & 39.6 & 48.2 & 40.7 & 8.8 & 2.3 & 35.2 & 88.9 \\
\hline $\mathrm{K}_{1} \mathrm{dw}$ & 23.1 & 19.4 & 1.5 & 0.2 & 44.2 & 52.3 & 43.9 & 3.4 & 0.5 & 42.5 & 96.2 \\
\hline $\mathrm{K}_{2} \mathrm{dw}$ & 20.9 & 18.2 & 3.7 & 0.3 & 43.1 & 48.5 & 42.2 & 8.6 & 0.7 & 39.1 & 90.7 \\
\hline $\mathrm{K}_{3} \mathrm{dw}$ & 19.4 & 17.8 & 3.6 & 0.4 & 41.2 & 47.1 & 43.2 & 8.7 & 1.0 & 37.2 & 90.3 \\
\hline $\mathrm{K}_{4} \mathrm{dw}$ & 20.8 & 17.6 & 3.2 & 0.2 & 41.8 & 49.8 & 42.1 & 7.7 & 0.5 & 38.4 & 91.9 \\
\hline
\end{tabular}

$\mathrm{K}_{1}-\mathrm{Pd} \mathrm{Hm}, \mathrm{K}_{2}-\mathrm{Ni} \mathrm{Hm}, \mathrm{K}_{3}-\mathrm{Co} \mathrm{Hm}, \mathrm{K}_{4}-\mathrm{Nd} \mathrm{Hm}$. 
The yield of TMB and Non-ar hydrocarbons decreases in reaction products in the samples calcinaned in wet-dry and dry-wet air stream conditions and the selectivity of the reaction increases (Table 1 ).

Regardless of calcination condition the samples modified with $\mathrm{Pd}^{2+}$ and $\mathrm{Ni}^{2+}$ cations exhibit higher activity and selectivity in disproportionation reaction of toluene than other MeHM (Nd, Co) samples (Table 1).

In the following studies the influence of temperature on catalytic activity of $\mathrm{H}$-mordenite zeolite catalysts modified with different metal cations calcinated in dry-wet air stream condition in disproportionation of toluene was studied. The results are shown in Table 1 and 2 .
As Table 1 and 2 show when the temperature increases from 300 to $400^{\circ} \mathrm{C}$ in metalcontaining $\mathrm{H}$-mordenite zeolite samples conversion of toluene and joint yield of benzene and xylenes increase (Figure).

The subsequent increase $\left(420^{\circ} \mathrm{C}\right)$ of temperature does not essentially influence on joint yield of benzene and xylenes (Table 1). But zirconium- and niobium-containing zeolite mordenite catalysts exhibit a high activity at $400^{\circ} \mathrm{C}$ in disproportionation reaction of toluene and due to joint yield of benzene and xylenes and selectivity of the reaction it is found to be higher than cobalt- and molybdenum-containing samples (Table 2).

Table 2. The influence of temperature on activity of H-mordenite zeolite catalysts, modified with transition element cations calcinated in dry-wet air stream condition in disproportionation of toluene. $V=3.1 \mathrm{~h}^{-1}, \mathrm{H}_{2} / \mathrm{CH}=3: 1$

\begin{tabular}{|c|c|c|c|c|c|c|}
\hline \multirow{2}{*}{ Element cations } & \multirow{2}{*}{$\begin{array}{c}\text { Temperature } \\
\mathrm{C}^{0}\end{array}$} & \multicolumn{4}{|c|}{ Yield of reaction products, $\%$} & \multirow{2}{*}{$\begin{array}{c}\text { Selectivity for } \\
\sum \mathrm{Ks}+\mathrm{B}, \%\end{array}$} \\
\hline & & Benzene & Xylenes & TMB & Non-ar hc & \\
\hline \multirow{3}{*}{$\mathrm{Pd}^{2+}$} & 300 & 16.5 & 20.1 & 0.5 & 0.0 & 98.7 \\
\hline & 350 & 19.4 & 23.1 & 1.5 & 0.2 & 96.2 \\
\hline & 400 & 21.4 & 23.7 & 3.1 & 0.4 & 92.8 \\
\hline \multirow{3}{*}{$\mathrm{Ni}^{2+}$} & 300 & 14.8 & 18.7 & 0.9 & 0.0 & 97.4 \\
\hline & 350 & 18.2 & 20.9 & 3.7 & 0.3 & 90.4 \\
\hline & 400 & 20.6 & 23.7 & 5.3 & 0.5 & 88.4 \\
\hline \multirow{3}{*}{$\mathrm{Co}^{2+}$} & 300 & 13.6 & 17.8 & 0.8 & 0.0 & 97.5 \\
\hline & 350 & 17.8 & 19.4 & 3.6 & 0.4 & 90.3 \\
\hline & 400 & 19.5 & 20.3 & 5.2 & 0.8 & 86.9 \\
\hline \multirow{3}{*}{$\mathrm{Mo}^{3+}$} & 300 & 12.8 & 17.7 & 0.7 & 0.0 & 97.8 \\
\hline & 350 & 16.6 & 19.8 & 3.4 & 0.3 & 90.8 \\
\hline & 400 & 18.4 & 21.1 & 4.8 & 0.5 & 88.2 \\
\hline \multirow{3}{*}{$\mathrm{Nd}^{3+}$} & 300 & 14.1 & 18.1 & 0.6 & 0.0 & 98.2 \\
\hline & 350 & 17.6 & 20.8 & 3.2 & 0.2 & 91.9 \\
\hline & 400 & 19.7 & 22.7 & 4.1 & 0.5 & 90.2 \\
\hline \multirow{2}{*}{$\mathrm{Zr}^{4+}$} & 350 & 10.4 & 13.1 & 1.6 & 1.0 & 93.3 \\
\hline & 400 & 20.2 & 22.4 & 3.8 & 0.3 & 91.2 \\
\hline \multirow{2}{*}{$\mathrm{Nb}^{5+}$} & 350 & 8.9 & 12.6 & 1.7 & 0.2 & 91.9 \\
\hline & 400 & 18.3 & 21.8 & 4.2 & 0.3 & 89.9 \\
\hline
\end{tabular}




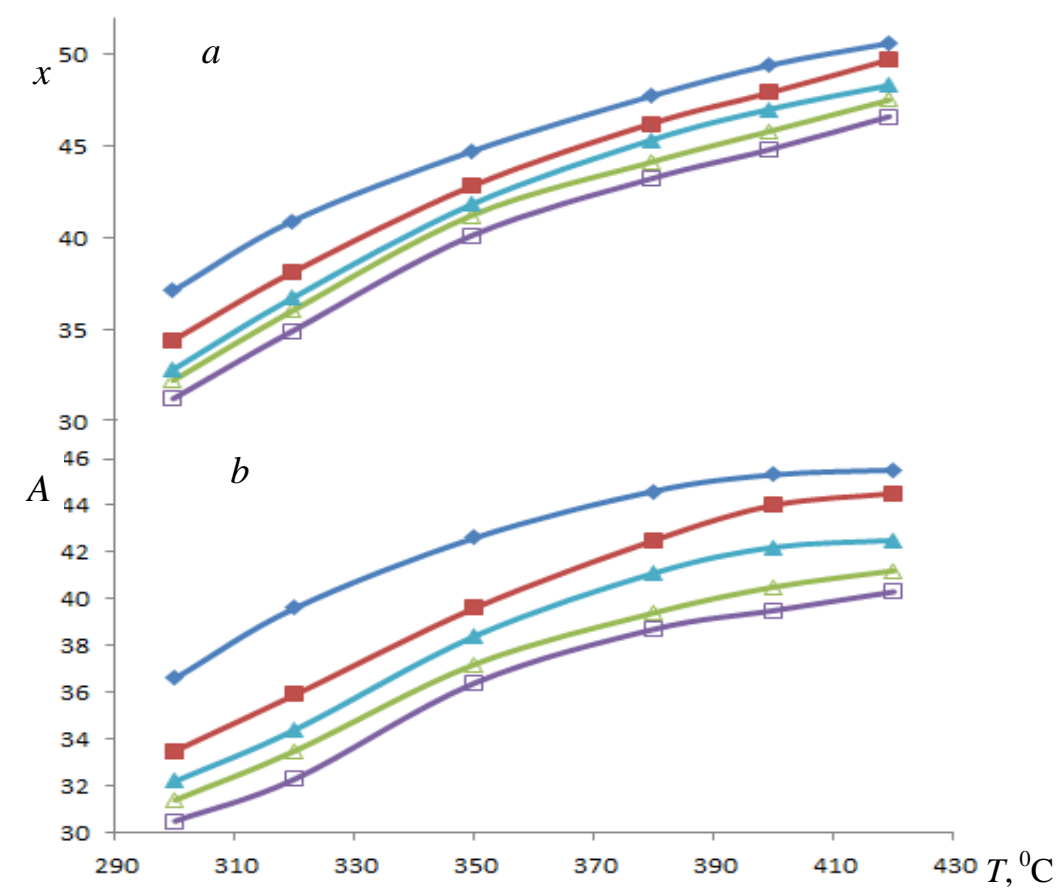

Dependence of toluene conversion $(a, x)$ and joint yield of benzene and xylenes $(\mathrm{b}, \mathrm{A})$ on the temperature in disproportionation of toluene on metal zeolite catalysts. $V_{\mathrm{t}}=3.1$

$\mathrm{h}^{-1} \mathrm{H}_{2} / \mathrm{CH}=3: 1 .-\mathrm{Pd} ; \square-\mathrm{Ni} ; \Delta-\mathrm{Nd} ; \Delta-\mathrm{Co} ; \square-\mathrm{Mo}$

But increase of reaction temperature causes the high yield of by-products (TMB and Non-ar hydrocarbons) and the selectivity of reaction decreases.

Thus, the results suggest that the activity and selectivity of a metal zeolite catalyst in disproportionation reaction of toluene can be regulated by calcinating them in dry-wet and wet-dry air stream conditions.

\section{References}

1. TCybulevskii A.M., Pak P.M., Zolotareva Z.V. Disproportcionirovanie toluola na nikel dealiumi- nirovannom mordenite. Neftehimiia. 1990. T. 20. № 3. S. 372-380.

2. Butler I. R., Xiao X., Hall Rosa. Toluene disproportionation catalyst, Pat. US 20100041934 A1. 2010.

3. Pat. 4956511 US. Toluene disproportionation process / Butler I. R., Randall J. Curtis. 1990.

4. Oliyev A.M, Ağayev V.Ş, Sarıcanov Ә.Ә. Müxtəlif silikat modullu H-Mordenit seoliti üzərində toluolun benzol və ksilollara disproporsionlaşması // Kimya Problemləri. 2018. № 2. S. 239-244.

5. Hak Sung LEE, Byung Kyu Kim. Bok Soo Park. Toluene disproportionation over metal loaded mordenites // Korean J. Chem. Eng. No 4. 1990. P. 243-249.

\section{TOLUOLUN DISPROPORSIONLAŞMA REAKSIYASINDA SINTETIK SEOLITIN - METAL KATIONLARI İLӘ MODIFIKASIYYA OLUNMUŞ MORDENITIN KATALITIK FOALLIQLARINA AKTIVLOŞMONIN TəSIRI}

\section{A.M.Đliyev, V.Ş.Ağayev, Ә.ə.Sarıcanov, R.Y.Mirzəyeva, S.R.Məmmədova}

Toluolun benzol və ksilollara disproporsionlaşma reaksiyasında müxtəlif hava mühitində aktivləşmiş metal katalionları ilə $\left(\mathrm{Pd}^{2+}, \mathrm{Ni}^{2+}, \mathrm{Co}^{2+}, \mathrm{Nd}^{3+}, \mathrm{Mo}^{3+}, \mathrm{Zr}^{4+}, \mathrm{Nb}^{5+}\right)$ modifikasiya olunmuş sintetik mordenit seolit $\left(\mathrm{SiO}_{2} / \mathrm{Al}_{2} \mathrm{O}_{3}=18\right)-$ katalizatorlarının $300-420^{\circ} \mathrm{C}$ temperatur intervalında katalitik fəallıqları tədqiq edilmişdir. Göstərilmişdir ki, tərkibində $\mathrm{Pd}^{2+}, \mathrm{Ni}^{2+}$ və $\mathrm{Nd}^{3+}$ kationları saxlayan seolit mordenit katalizatorları $\mathrm{Co}^{2+}, \mathrm{Mo}^{3+}, \mathrm{Zr}^{4+}, \mathrm{Nb}^{5+}$ tərkibli katalizatorlara nisbətən yüksək fəallı̆̆a malikdirlər. Müəyyən olunmuşdur ki, tədqiq olunan reaksiyada benzol və ksilolların birgə çıxımı və selektivliyi quru-nəm hava mühitində aktivləşmiş katalizatorlarda maksimum olur.

Açar sözlar: disproporsionlaşma, toluol, seolit, mordenit, benzol, ksilollar, kation, aktivlaşmə, modifikasiya. 


\section{ВЛИЯНИЕ АКТИВАЦИИ НА КАТАЛИТИЧЕСКУЮ АКТИВНОСТЬ СИНТЕТИЧЕСКОГО ЦЕОЛИТА - МОРДЕНИТА, МОДИФИЦИРОВАННОГО КАТИОНАМИ МЕТАЛЛОВ, В РЕАКЦИИ ДИСПРОПОРЦИОНИРОВАНИЯ ТОЛУОЛА}

\section{А.М.Алиев, В.Ш.Агаев, А.А.Сарыджанов, Р.Ю.Мирзоева, С.Р.Мамедова}

Исследовано влияние активации на каталитические свойства катализаторов, модифицированных катионами металлов $\left(\mathrm{Pd}^{+2}, \mathrm{Ni}^{2+}, \mathrm{Co}^{2+}, \mathrm{Nd}^{3+}, \mathrm{Mo}^{3+}, \mathrm{Zr}^{4+}, \mathrm{Nb}^{5+}\right)$, синтетического цеолита, морденита $\left(\mathrm{SiO}_{2} / \mathrm{Al}_{2} \mathrm{O}_{3}=18\right)-{ }_{\text {в }}$ реакции диспропорционирования толуола в бензол и ксилолы в интервале температур $300-420^{\circ} \mathrm{C}$. Найдено, что катализаторы, модифицированные катионами $\mathrm{Pd}^{+2}, \mathrm{Ni}^{2+}$ и $\mathrm{Nd}^{3+}$ цеолита, морденита проявляют относительно более высокую активность и селективность по сравнению с образцом морденита, содержащего катионы Со ${ }^{2+}$, $\mathrm{Mo}^{3+}, \mathrm{Zr}^{4+}, \mathrm{Nb}^{5+}$. Установлено, что в изученных условиях наибольшей активностью (по выходу суммы бензол и ксилолы) и селективностью обладают образцы, активированные в сухо-влажной среде воздуха.

Ключевые слова: диспропорционирование, толуол, цееолит, морденит, бензол, ксилоль, катион, активация, модификаичя. 